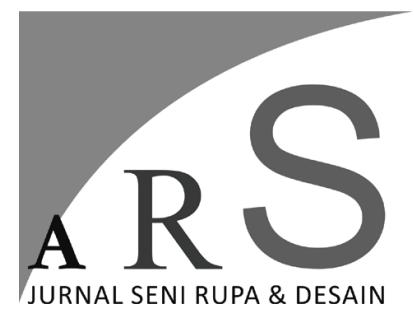

Volume 23 Nomor 2 Mei - Agustus 2020

\section{EKSPERIMEN TAFRIL UNTUK LUKISAN CAT AIR}

\section{Deni Junaedi, Andrea Gani Hidayat}

Prodi Seni Murni, Fakultas Seni Rupa, Institut Seni Indonesia Yogyakarta. Jl. Parangtritis, Km. 6,5 Sewon, Bantul Yogyakarta

E-mail: denijunaedipainting@gmail.com

\begin{abstract}
ABSTRAK
Kertas merupakan pasangan konvensional untuk tafril atau bidang lukisan cat air; sebagai bentuk kreativitas, peran kertas perlu diganti dengan tafril berbahan lain. Untuk itu, penelitian berjudul "Eksperimen Tafril untuk Lukisan Cat Air" ini mengajukan rumusan penciptan: "Bagaimanakah karakter tafril dari kulit jeruk kering, kulit kacang kering, dan daun pisang kering jika digunakan untuk lukisan cat air? Dari ketiga tafril alami yang berasal dari tumbuhan kering tersebut, manakah bahan yang paling cocok untuk cat air?” Dengan metode improvisasi, eksperimen dilakukan menggunakan tafril berbahan kulit jeruk kering, kulit kacang kering, dan daun pisang kering. Karakter tafril yang diperhatikan meliputi daya serap, warna dasar, dan tekstur. Karena cat air bersifat transparan, tafril yang cocok adalah memiliki daya serap kuat, berwarna dasar terang, dan teksturnya tidak terlalu kasar juga tidak terlalu halus. Dalam penelitian ini, tafril yang memiliki karakter tersebut adalah kulit jeruk kering. Adapun tafril dari kulit kacang kering memiliki tekstur yang terlalu kasar dan tafril dari daun pisang tidak memiliki daya serap tinggi juga warna dasarnya kurang terang.
\end{abstract}

Kata kunci: lukisan, cat air, tafril, tumbuhan kering

\begin{abstract}
Tafril Experiments For Water Painting. Paper is a conventional pair for tafril or watercolor painting fields; as a form of creativity, the role of paper needs to be replaced with other ingredients made of paper. For this reason, the study entitled "Tafril Experiments for Watercolor Painting" proposes the creation formula: "What is the character of tafril from dried orange peel, dried peanut skin, and dried banana leaves when used for watercolor painting? Of the three natural tafrils derived from dried plants, which one is the most suitable material for watercolors? "With the improvised method, experiments were carried out using tafril made from dried orange peels, dried peanut skins, and dried banana leaves. The character of the tafril that is considered includes absorption, base color, and texture. Because watercolors are transparent, suitable tafril is to have a strong absorption, brightly colored base, and texture not too rough nor too smooth. In this study, tafril which has these characteristics is dried orange peel. The tafril from dried peanut skin has a texture that is too coarse and the tafril from banana leaves does not have a high absorbency nor is the base color less bright.
\end{abstract}

Keywords: painting, watercolor, tafril, dried plants 


\section{Pendahuluan}

Lukisan cat air umumnya menggunakan kertas aquarel sebagai tafril, yaitu bidang yang dilukisi. Kertas jenis itu memang menjanjikan beragam teknik artistik, seperti wet on wet atau penerapan cat air encer pada kertas yang basah. Namun demikian, karena tuntutan kreativitas dalam berkesenian, eksplorasi tafril untuk cat air perlu dilakukan agar melahirkan berbagai kemungkinan wujud artistik baru.

Mengupayakan bentuk baru dalam dunia seni merupakan tindak kreatif. Kreativitas ini menjadi keniscayaan berkesenian, karena tanpa laku kreatif kesenian akan membosankan. Kreativitas dalam seni lukis dapat dilakukan pada berbagai aspek, seperti objek, teknik, alat, maupun bahan yang terdiri dari pewarna dan tafril. Upaya kreatif dalam penelitian ini ada pada ranah bahan, khususnya pada tafril. Adapun pewarna yang digunakan adalah cat air.

Cat air memerlukan jenis tafril yang mudah menyerap. Tidak seperti cat minyak, cat air tidak dapat menempel pada bidang yang licin dan berpori-pori rapat. Kertas aquarel biasa digunakan untuk lukisan cat air karena daya serap kertas tersebut kuat. Dengan demikian, penggantian kertas dengan jenis tafril yang lain untuk cat air perlu mempertimbangkan daya serap bahan penggantinya. Bahan-bahan alami dari tumbuhan kering, seperti pelepah pisang, daun, atau kapas diasumsikan dapat digunakan sebagai penggantinya.

Selain itu, sifat khas cat air yang paling terkenal adalah transparan. Warna transparan berarti tembus pandang, dengan demikian warna tafril atau warna cat yang ada di bagian bawah akan tetap tampak. Untuk membuat warna putih misalnya, lukisan cat air di kertas akan memanfaatkan warna kertas tersebut. Hal ini berbeda dengan cat lain yang cenderung memiliki sifat menutup atau opaque, seperti pada karakter cat minyak, car akrilik, atau bahkan cat poster.

Karena cat air bersifat transparan, maka perlu dipilih bahan alami dari tumbuhan kering yang berwarna terang, sebab jika warna dasarnya adalah gelap maka warna cat air tidak akan terlihat. Kayu sonokeling yang berwarna kehitam-hitaman, misalnya, tidak dapat digunakan sebagai tafril cat air; sebaliknya, kayu sengon dapat menjadi pilihan karena berwarna terang. Selain itu kayu sengon juga mudah menyerap air.

Tafril berbahan alami dari tetumbuhan tadi juga mesti kering sebelum digunakan untuk melukis. Hal ini karena bahan alami dari tumbuhan kerap kali memiliki perbedaan warna setelah kering dibandingkan dengan ketika bahan itu masih basah. Contoh yang mudah ditemui adalah daun, saat basah berwarna hijau ketika kering berwarna coklat. Maka, untuk eksperimen lukisan cat air ini digunakan bahan-bahan alami dari tetumbuhan yang telah kering. Bahan-bahan tersebut disusun dan direkatkan di panel MDF. Tafril yang digunakan untuk penelitian ini berasal dari kulit jeruk kering, kulit kacang kering, dan daun pisang kering.

\section{Rumusan Masalah}

Bagaimanakah karakter tafril dari kulit jeruk kering, kulit kacang kering, dan daun pisang kering jika digunakan untuk lukisan cat air? Dari ketiga tafril alami yang berasal dari tumbuhan kering tersebut, manakah bahan yang paling cocok untuk cat air?

\section{Penelitian Terdahulu}

Penelitian eksperimen tentang proses dan karya kreatif lukisan cat air dengan tafril berbahan alami dari tumbuhan kering khususnya yang dibuat dari kulit jeruk, kulit kacang, dan daun pisang - belum dilakukan. Namun demikian, penelitian eksperimental yang terkait dengan medium atau pengencer cat air telah ada, penelitian tentang pewarna yang berbasis air juga telah dilakukan, demikian juga penelitian tentang eksperimen tafril yang bukan berasal dari tumbuhan kering telah dijalankan, banyak di antara penelitian itu menggunakan pewarna yang bersifat opaque. Upaya kreatif yang dilakukan terhadap cat air biasanya menyentuh aspek alat sebagai alternatif pengganti kuas agar menghasilkan efek yang unik. Berikut ini beberapa pustaka terkait hal tersebut.

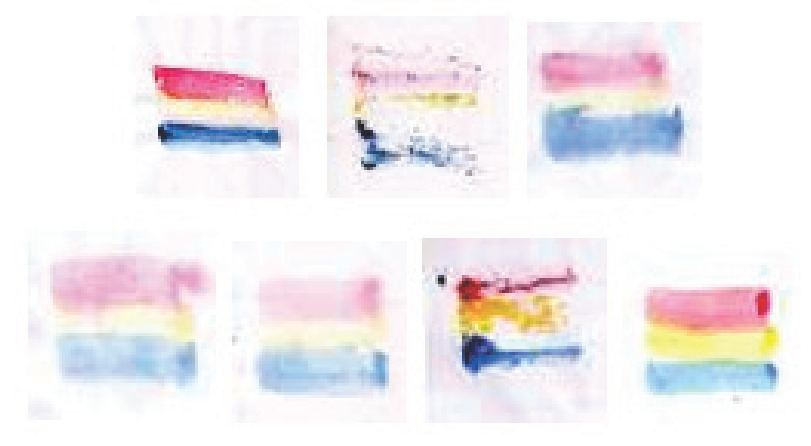

Gambar 1. Hasil penelitian cat air dicampur dengan bensin, minyak tanah, Fanta, Sprite, Coca-Cola, Baygon, Rapika (Hasyim and Mutmainah 2013:65-69) 
Dalam artikel berjudul "Eksperimen Pencampuran Pewarna Cat Air dengan Zat Cair (Non Air)" yang dimuat dalam Jurnal Pendidikan Seni Rupa, Moch. Hasyim Asy'ari dan Siti Mutmainah (2013:65-69) melakukan ekperimen pencampuran cat air dengan media selain air. Mereka menambahkan bensin, minyak tanah, minuman bersoda merek Fanta, Sprite, CocaCola, obat nyamuk cair Baygon, dan pewangi pakaian Rapika. Peneliti dari Universitas Negeri Surabaya (UNESA) itu menyimpulkan bahwa medium bahan bakar minyak bumi dari empat bahan bakar minyak bumi hanya spiritus yang dapat menjadi alternatif medium cat air. Medium soft drink pun dapat menjadi alternatif campuran cat air. Untuk bahan kimia rumah tangga, pewangi pakaian (Rapika) dapat digunakan sebagai alternatif campuran cat air.
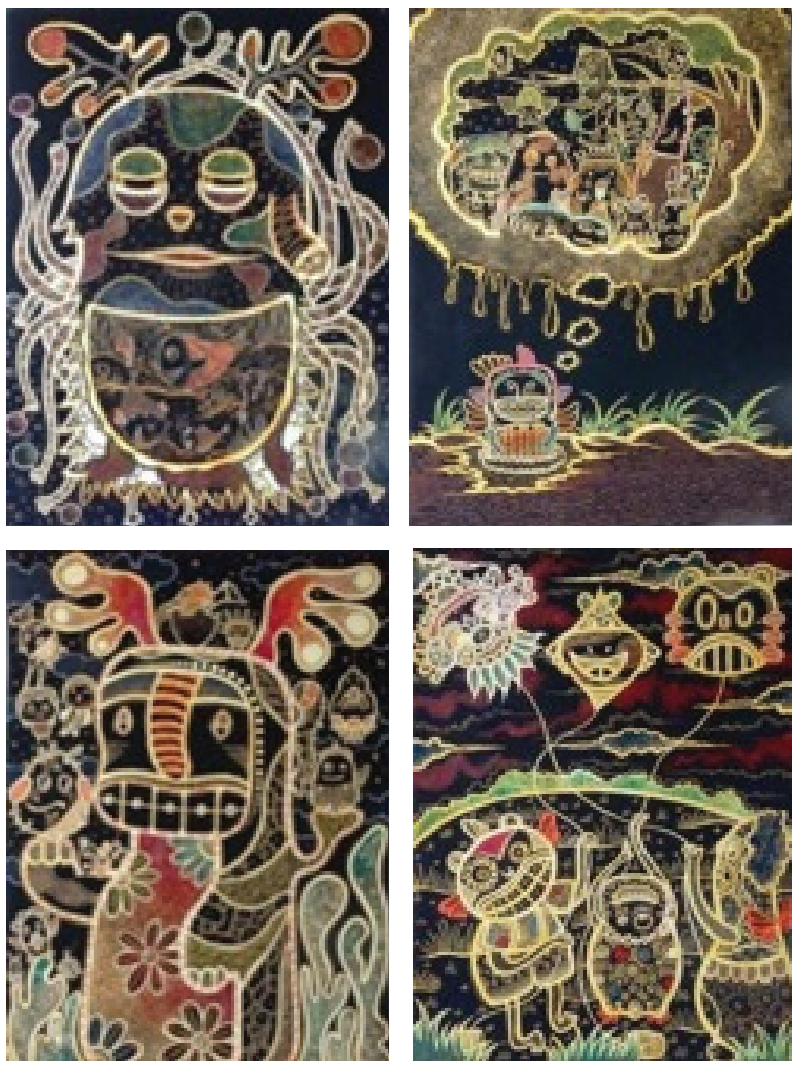

Gambar 2. Hasil penelitian lukisan pada tafril kertas foto "terbakar" dengan pearna dari pensil warna, cat air, cat akrilik, dan cat minyak

(Evitadyan and Lodra 2015:57-63)

Sementara itu, Ratna Adenia Evitadyan dan I. Nyoman Lodra (2015:57-63) melakukan eksperimen seni lukis pada tafril kertas foto "terbakar". Kedua mengerjakannya dengan berbagai jenis bahan pewarna, yaitu pensil warna, cat air, cat akrilik, dan cat minyak. Lewat artikel berjudul "Eksperimen Media Melukis Dengan Kertas Foto "Terbakar"” yang dimuat dalam Jurnal Pendidikan Seni Rupa tahun 2015, keduanya menyatakan bahwa proses eksperimen melukis media kertas foto "terbakar" dilakukan dengan cara menggores kertas foto menggunakan pena kodok. Saat menggores sangat dalam maka warna yang dihasilkan adalah putih kekuningan, saat menggores tidak terlalu dalam warna yang diperoleh ialah kuning, jika digores tipis akan mucul warna orange, dan jika lebih tipis lagi akan berwarna merah. Khusus untuk cat air, karena permukaan kertas foto yang licin mengakibatkan warna cat air tidak mudah menempel.

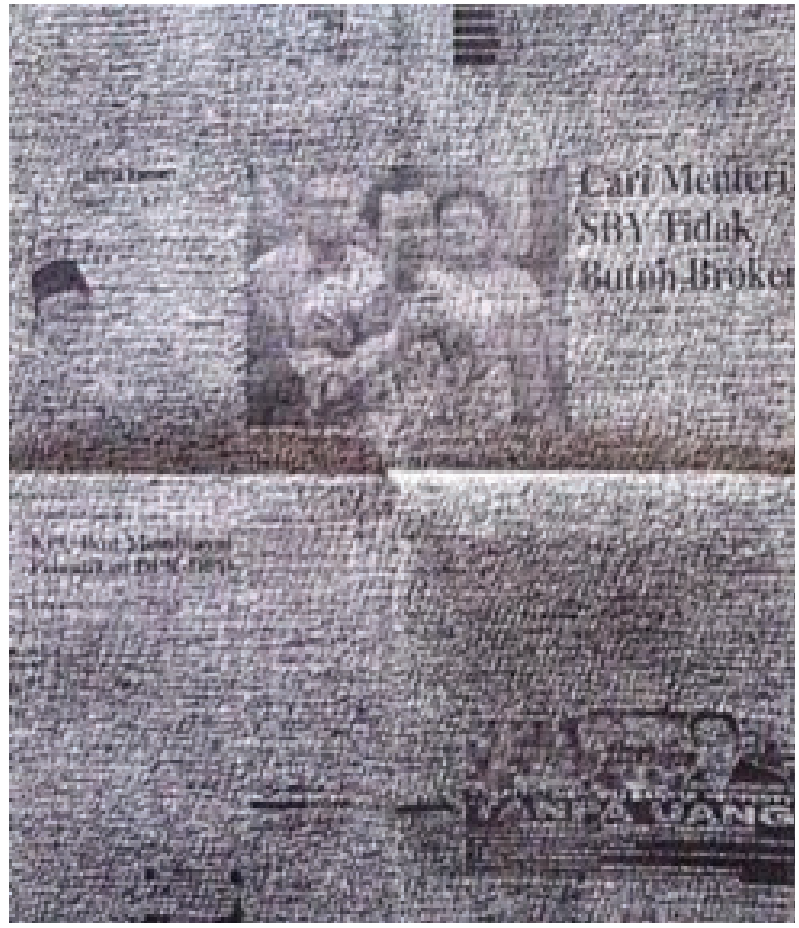

Gambar 3, Lukisan dengan tafril koran bekas; Beng Herman, "Perjalanan Hidup 1", 2015, ballpoint pada kertas koran bekas, $60 \times 40 \mathrm{~cm}$ (Nur and Winarno 2018:732-39)

Penelitian yang dilakuakan terhadap seniman Beng Herman yang melakukan ragam penggunaan tafril dijalankan oleh Ahadien Raidy Nur dan Winarno (2018:732-39). Pada artikel berjudul "Kajian Media Pada Karya Lukis Beng Herman Periode Tahun 2013-2015" yang dimuat dalam Jurnal Pendidikan Seni Rupa tahun 2018, keduanya menelisik penggunaan media yang tidak konvensional pada lukisan Beng Herman. Seniman ini menggunakan kertas koran sebagai tafril. Bahkan ia tidak segan memakai sampul katalog maupun lemari es. 


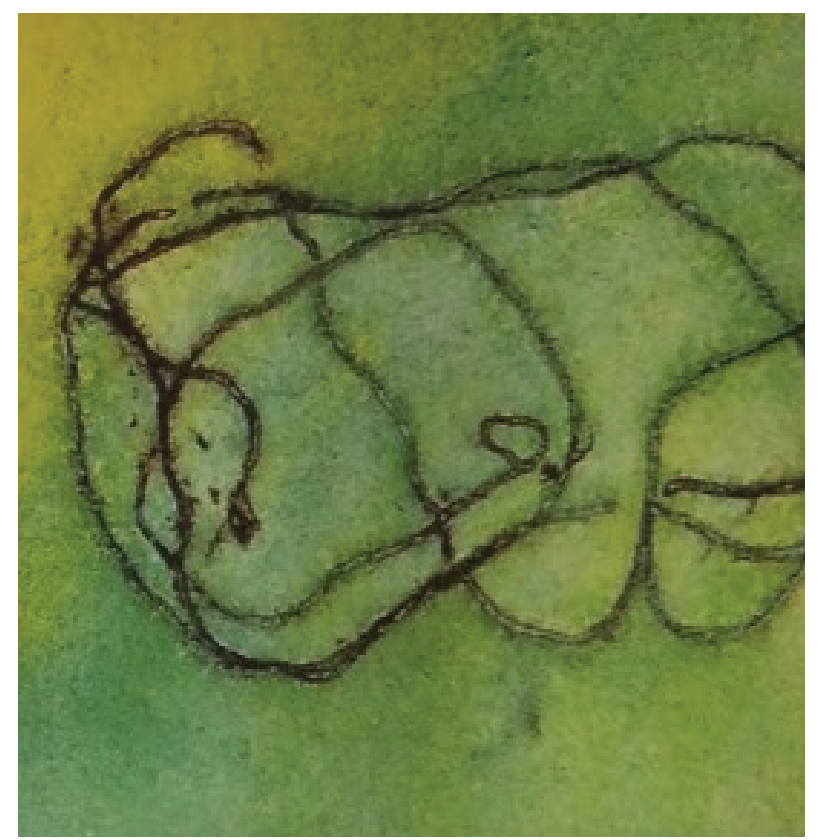

Gambar 4. Benang sebagai alat pengganti kuas pada lukisan cat air

(Comella 1996:11)

Adapun eksperimen terhadap alat yang digunakan untuk cat air dilakukan oleh $\mathrm{M}$. Angels Comella (1996:11). Dalam buku berjudul Watercolor ia melakukan beragam eksplorasi. Antara lain adalah menggunakan benang yang dicelupkan dalam cat berwarna gelap. Lalu benang tersebut diletakkan dalam kertas yang telah diberi cat air berwarna terang dalam keaadaan masih basah. Setelah keduanya kering, benang tersebut diangkat. Hasilnya, pada kertas tercetak lengkungan-lengkungan artistik bekas benang.

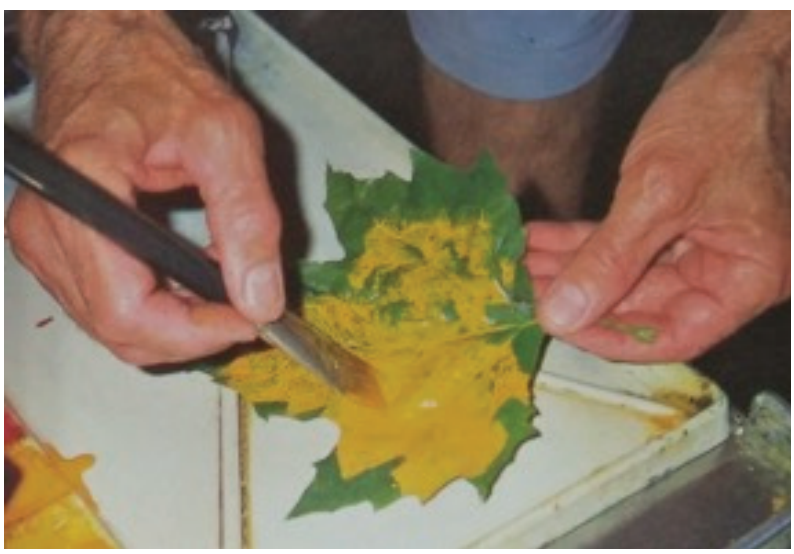

Gambar 5. Membuat bentuk daun dengan cat air dengan cara mengecap menggunakan daun (Appellof 1992:188)

Demikian pula, eksperimen dilakukan oleh John Koser. Lewat buku Everything You Ever Wanted to Know About Watercolor yang ditulis oleh Marian E. Appellof (1992:188), Koser membuat lukisan dengan cara membubuhkan cat air pada suatu daun. Lalu daun itu dicapkan pada selembar kertas. Maka hasilnya berupa seni grafis bentuk daun tersebut.
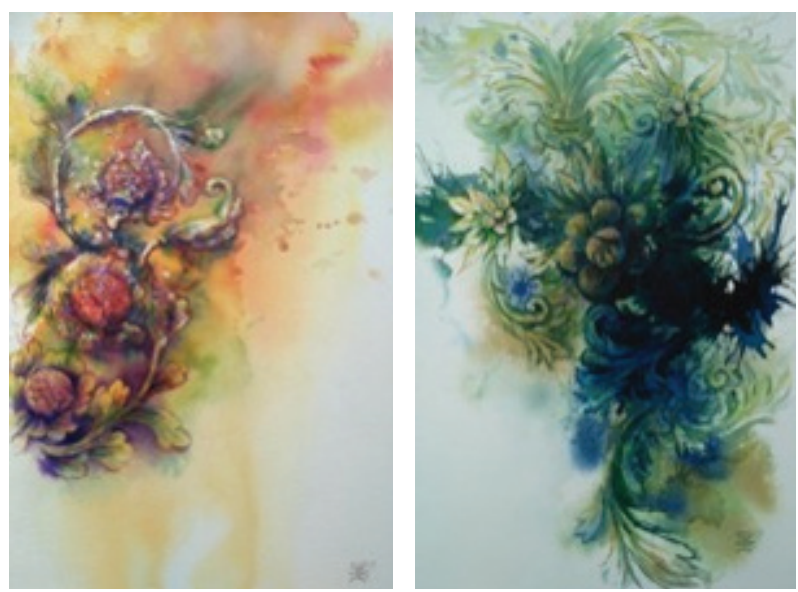

Gambar 6. Lukisan hasil penelitian "Komposisi Efek Spontan Cat Air dengan Sulur Tradisional Yogyakarta"; "Sulur Jogja", 2017, cat air di kertas, 30,5 x 45,5 cm; dan

"Sulur Pintu Kotagede", 2017, cat air di kertas, 30,5 x 45,5 cm (Junaedi and K. 2017:31-34)
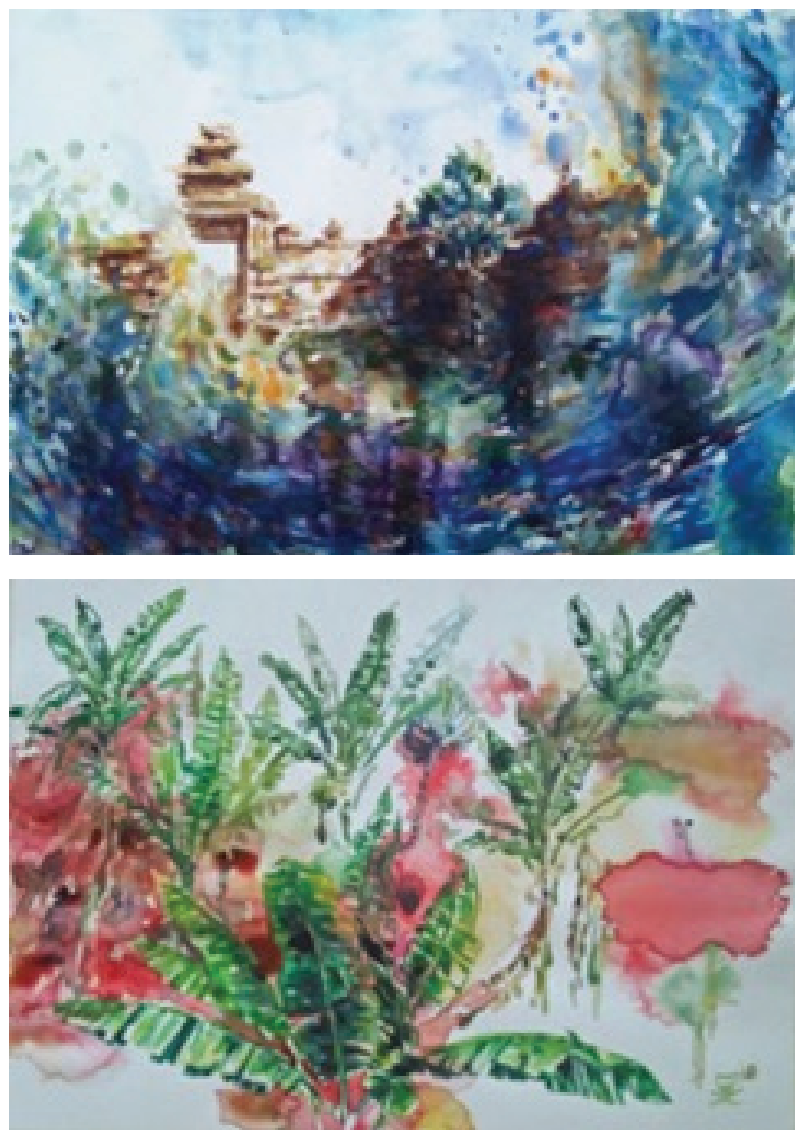

Gambar 7. Lukisan hasil penelitian "Estetika Closure dengan Efek Cat Air pada Praktek Melukis Langsung di Luar Studio"; "Makam Raja-Raja Mataram" 2018, cat air di kertas, 29,5 x $42 \mathrm{~cm}$; "Sekumpulan Pohon Pisang", 2018, cat air di kertas, 29,5 x $42 \mathrm{~cm}$ (Junaedi and Tanos 2018:22-27) 

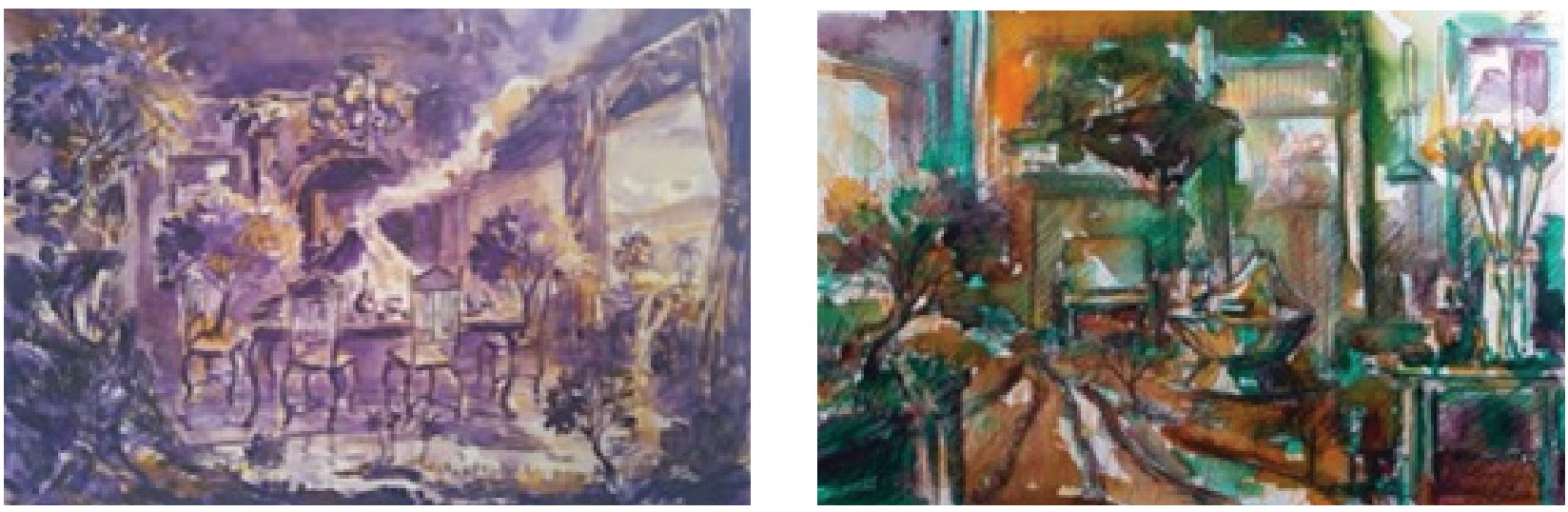

Gambar 8. Lukisan hasil penelitian "Komposisi Warna Split Komplementer untuk Penciptaan Lukisan Lanskap Cat Air"; "Lanskap Poros Ungu”, 2018, cat air di kertas, 45,5 x 30,5 cm;"Lanskap Poros Oranye”, 2018, cat air di kertas, 45,5 x 30,5 cm (Junaedi and Tanos 2018:25-26)

Penelitian ini juga merupakan bagian dari roadmap penelitian yang terkonsentrasi pada penciptaan lukisan cat air. Tahun 2017, penelitian "Komposisi Efek Spontan Cat Air dengan Sulur Tradisional Yogyakarta pada Penciptaan Lukisan" dibuat di bawah skema Penelitian Dosen Muda Mandiri Lembaga Penelitian ISI Yogyakarta (Junaedi and K. 2017). Selanjutnya, pada 2018, penelitian "Estetika Closure dengan Efek Cat Air pada Praktek Melukis Langsung di Luar Studio” dijalankan dengan dana Penelitian Dosen Pemula DIKTI (Junaedi and Wicaksono 2018). Pada tahun yang sama, penelitian "Komposisi Warna Split Komplementer untuk Penciptaan Lukisan Lanskap Cat Air" dalam skema Penelitian Dosen Muda Mandiri Lembaga Penelitian ISI Yogyakarta (Junaedi and Tanos 2018).

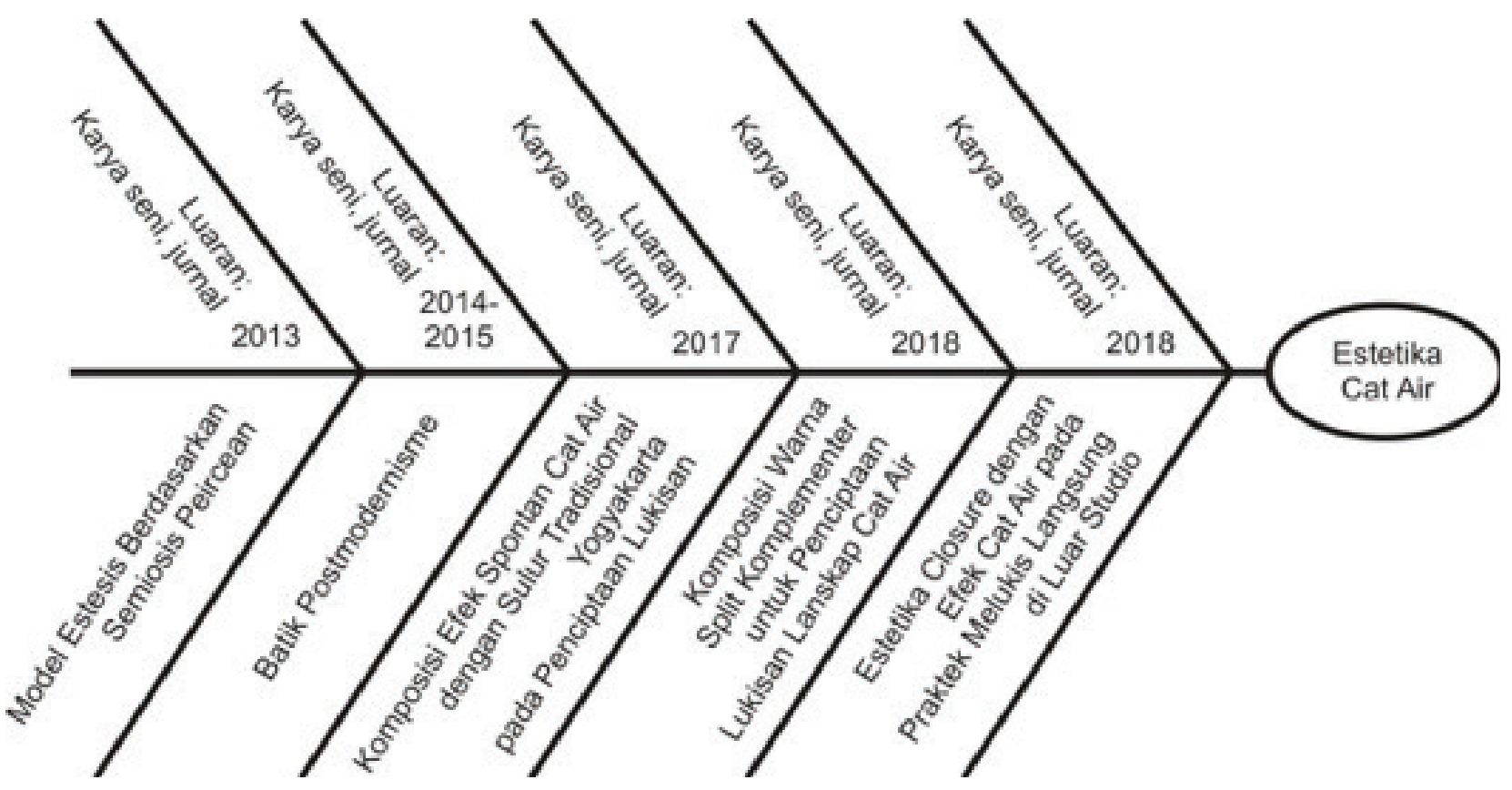

Gambar 9. Diagram tulang ikan (fish bone) perjalanan (roadmap) penelitian (Junaedi dan Tanos) 


\section{Landasan Teori}

Transparan merupakan sifat khas cat air. Hugh Greer (2010:4) lewat artikel berjudul "Snow Demo" dalam jurnal Watercolor Studio menyatakan bahwa dengan cat air ia akan melukis setransparan mungkin, khususnya saat mengikuti kompetisi. Bahkan ia menyatakan bahwa kompetisi cat air kerap kali mensyaratkan peserta untuk menunjukkan penggunaan warna putih kertas.

Bahkan ketika bermain warna gelap sekalipun Laurin McCracken (2011:4) tetap dalam kerangka transparan. Pada artikel "Techniques from a Studio Painter" di jurnal Watercolor Studio ia menyatakan pembuatan warna gelap dengan campuran antara warna Prussian Blue dan Alizarin Crimson keluaran cat air tube produksi Winsor Newton ditambah warna Mineral Violet dari pabrik Holbein. Ia menambahkan, cat air akan menjadi agak bersifat opaque ketika ditambah warna-warna coklat tanah.

Sementara itu, Joe Garcia (2002:36-37) dalam Mastering the Watercolor Wash merumuskan bahwa terdapat empat teknikdalam pembuatan dasar cat air, yaitu: datar (flat), gradasi (gradated), basah pada basah (wet-into-wet), dan lelehan (streaked). Datar merupakan pembuatanwarna satu nada dalam suatu bidang. Gradasi adalah perubahan tonalitas atau gelap terang warna secara berangsur dalam suatu permukaan. Basah pada basah merupakan teknik penerapan cat air pada permukaan kertas yang telah dibasahi sehingga warna akan terbentuk atau tercampur secara spontan. Lelehan adalah teknik yang dibuat dengan cara peneraan cat air di atas kertas basah lalu salah satu sisi kertas diangkat agar cat air tersebut mengalir ke arah yang dikehendaki.

\section{Tujuan Penelitian}

Tujuan penelitian ini adapah pembuatan lukisan cat air dengan tafril berbahan alami dari tumbuhan kering. Luaran penelitian berupa laporan penelitian, karya seni, artikel ilmiah di jurnal nasional, dan kekayaan intelektual.

\section{Manfaat Penelitian}

Penelitian ini memiliki manfaat untuk beberapa pihak, yaitu untuk mayarakat seni, institusi akademis, peneliti lain, maupun peneliti sendiri. Untuk masyarakat seni, penelitian ini dapat memperkaya ragam artistik dalam penciptaan lukisan. Untuk institusi akademis, kajian ini diharapkan mampu mengembangkan suasana akademis dalam penciptaan seni. Untuk peneliti lain, hal-hal yang memungkinkan untuk dikembangkan dengan penelitian ini dapat ditindaklanjuti melalui penelitian lanjutan. Untuk peneliti sendiri, penelitian ini akan menjadi jejak kepakaran dalam bidang seni rupa.

\section{Metode Penelitian}

Metode penelitian ini adalah improvisasi. Penelitian dilakukan dengan cara percobaanpercobaan, memilih, membedakan, maupun menimbang karya seni yang dihasilkan. Materi penelitian ini adalah penciptaan lukisan cat air di tafril berbahan alami dari tumbuhan kering.

Bahan yang digunakan adalah cat air dan tafril berbahan alami dari tumbuhan kering, yaitu: kulit jeruk, kulit kacang, dan daun pisang. Bahan alami tersebut disusun dan direkatkan pada panel MDF (Medium-density fibreboard) berbentuk segi empat. Perekatnya menggunakan lem tembak ( $g l u$ gun) maupun lem kayu. Setelah lukisan selesai diberi pelapis fixatif yang disemprotkan. Alat yang dipakai adalah beragam kuas cat air, alat untuk lem tembak, penyemprot air, pita perekat, dan kertas tissue.

Variabel penelitian ini adalah lukisan cat air dengan tafril berbahan alami dari tumbuhan kering. Penciptaan lukisan cat air dengan tafril berbahan kulit jeruk, kulit kacang, dan daun pisang ini menjadi nilai kebaruan (novelty) penelitian ini.
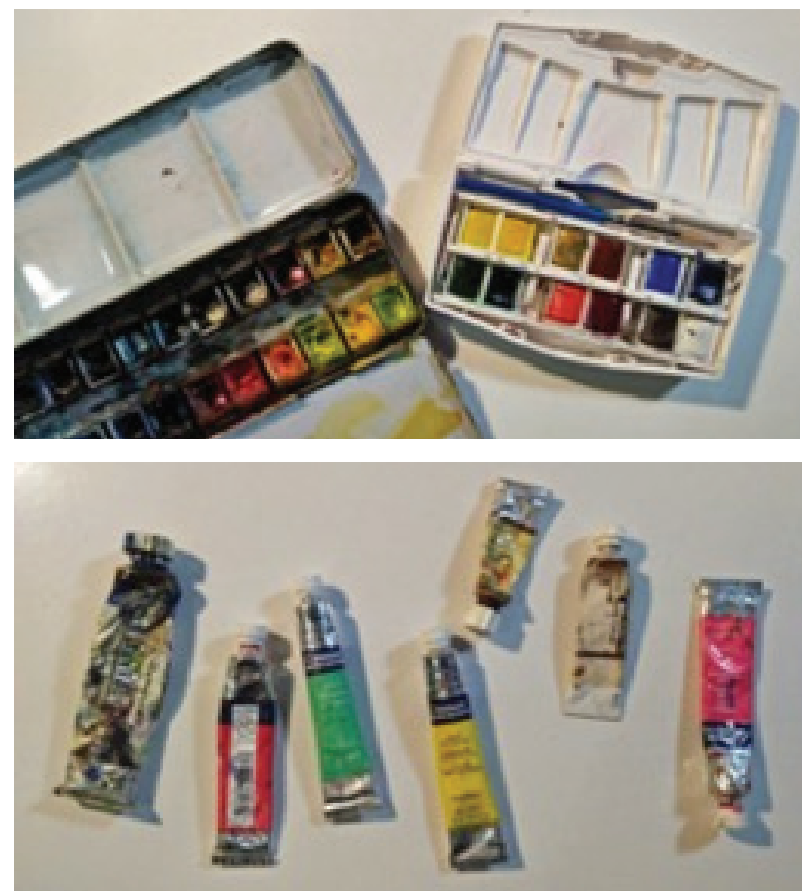

Gambar 10. Cat air jenis kering dan tube (Junaedi dan Tanos) 


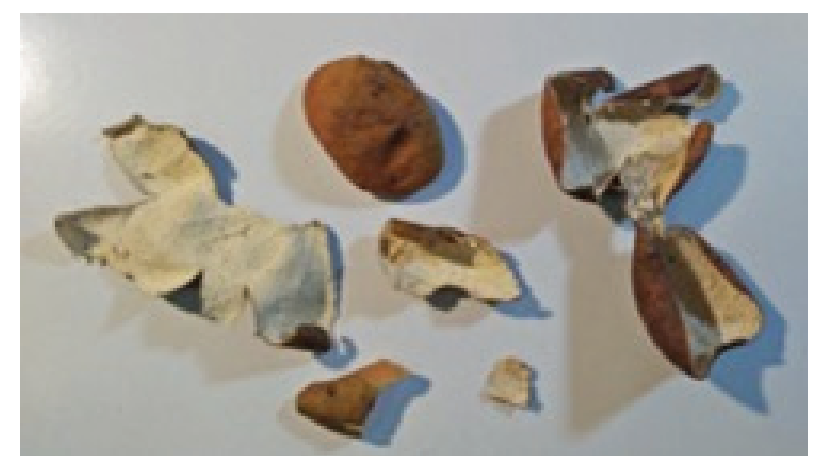

Gambar 11. Kulit jeruk untuk tafril lukisan cat air (Junaedi dan Tanos)

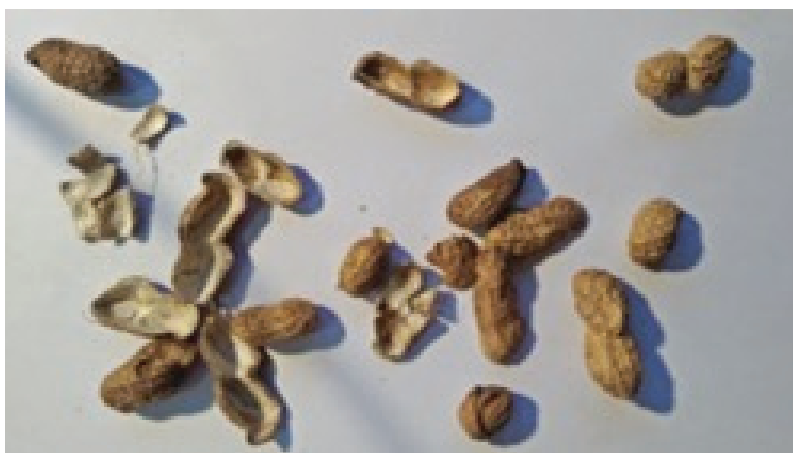

Gambar 12. Kulit kacang untuk tafril lukisan cat air (Junaedi dan Tanos)

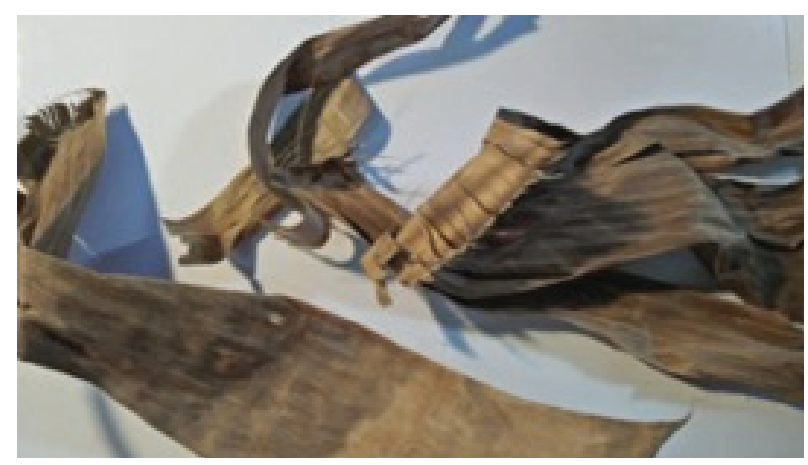

Gambar 13. Daun pisang untuk tafril lukisan cat air (Junaedi dan Tanos)

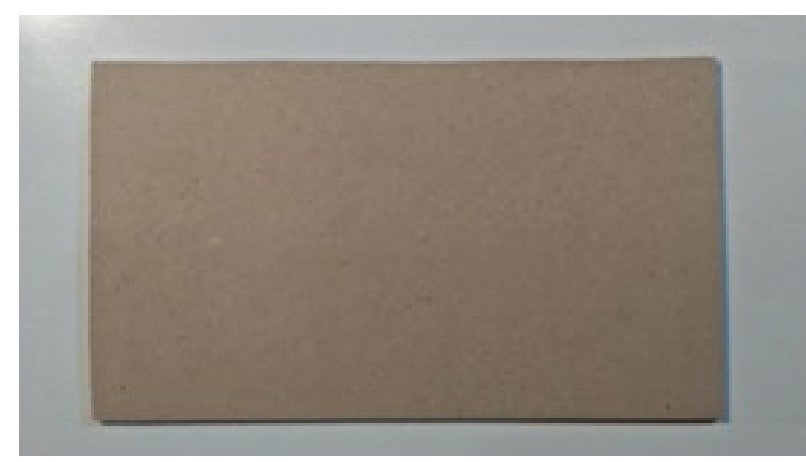

Gambar 14. Panel MDF (Medium-density fibreboard) (Junaedi dan Tanos)

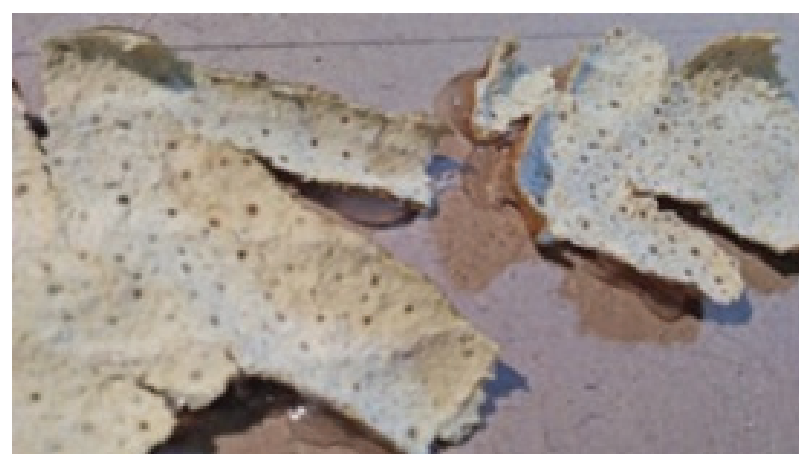

Gambar 15. Proses perekatan kulit jeruk pada MDF menggunakan lem tembak (Junaedi dan Tanos)

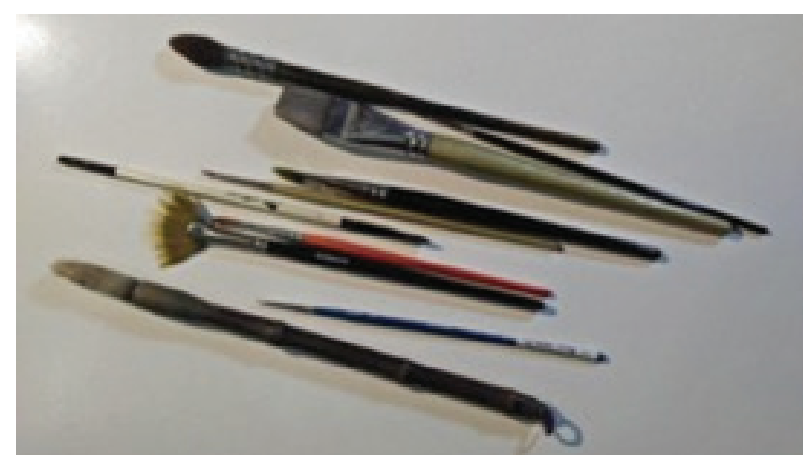

Gambar 16. Kuas cat air (Junaedi dan Tanos)

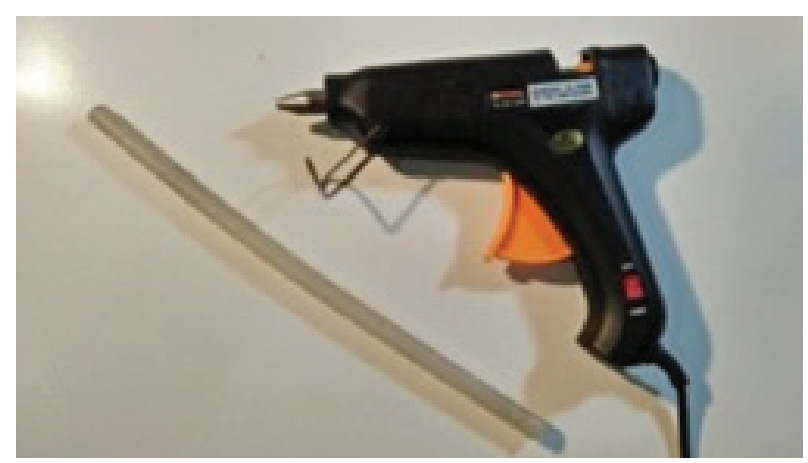

Gambar 17. Lem tembak (glu gun) (Junaedi dan Tanos) 


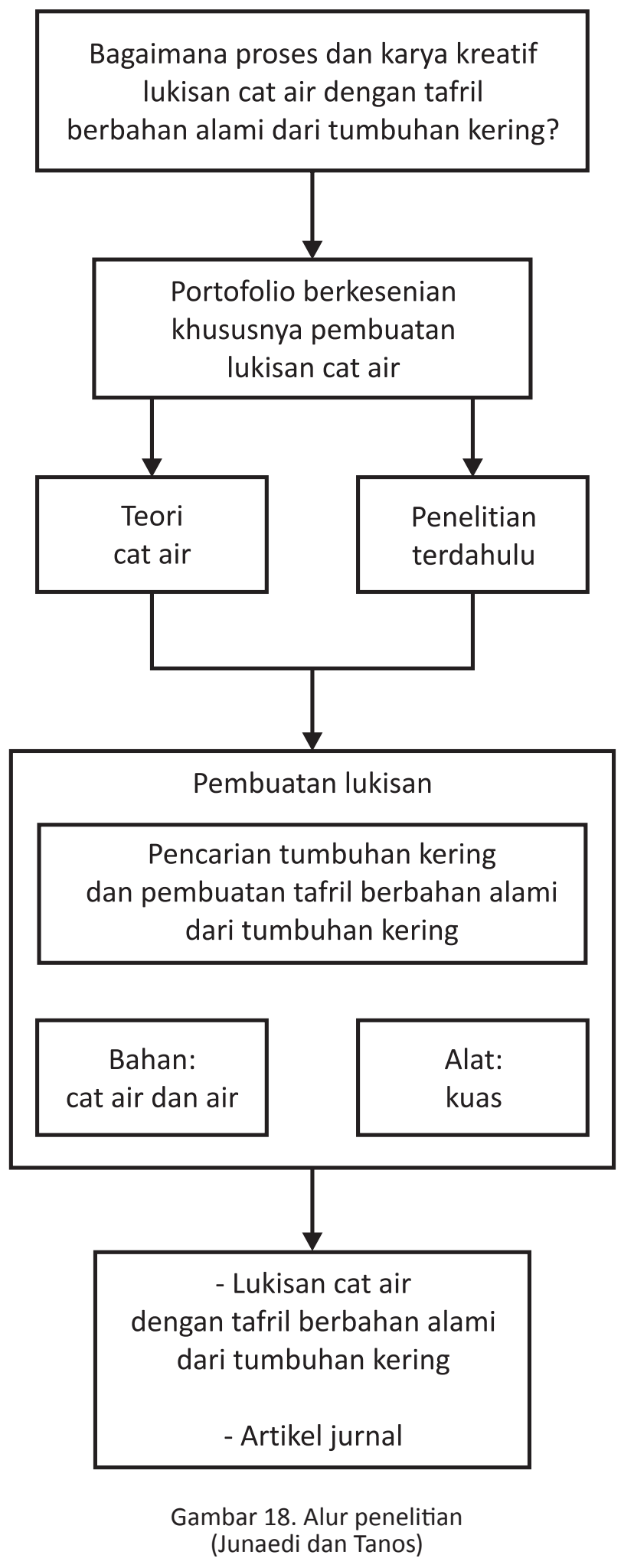

\section{Hasil Yang Dicapai}

Berikut ini adalah hasil penelitian lukisan cat air yang dibuat pada tafril kulit jeruk kering, kulit kacang kering, dan daun pisang kering. Karakter masing-masing tafril terhadap sifat cat air menjadi penekanan.

\section{Tafril Kulit Jeruk Kering}

Lukisan pertama pada penelitian ini dibuat dengan tafril kulit jeruk yang telah dikeringkan pada terik matahari selama beberapa hari. Lalu bahan itu ditempelkan pada panel MDF. Penempelan menggunakan lem tembak. Lem ini digunakan karena mampu menjangkau rongga yang ada di antara sisi kulit jeruk yang melengkung dengan MDF.

Sisi kulit jeruk bagian dalam tetap berwarna terang kendati telah dijemur di terik matahari, dengan demikian cocok untuk tafril cat air yang bersifat transparan. Pori-pori kulit ini tergolong besar. Daya serapnya termasuk tinggi sehingga bagus untuk cat bermedia aquarel. Kulit jeruk memiliki pola bintik-bintik, hal ini perlu direspon dengan bentuk tertentu, dalam penelitian ini menjadi bentuk bunga. Karena kulit jeruk awalnya berbentuk bulat, maka ketika menjadi tafril bidang datar perlu dipotong dalam ukuran yang relatif kecil. Pemotongan dilakukan dengan tangan, bukan dengan gunting atau cutter, agar hasil yang terbentuk masih tampak alami.

Data lukisan pertama dalam penelitian ini adalah sebagai berikut; judul: "Tafril Kulit Jeruk Kering untuk Lukisan Cat Air"; tahun: 2019; bahan: cat air, kulit jeruk kering, mdf, lem tembak, fixatif; ukuran: $15 \times 28 \mathrm{~cm}$.

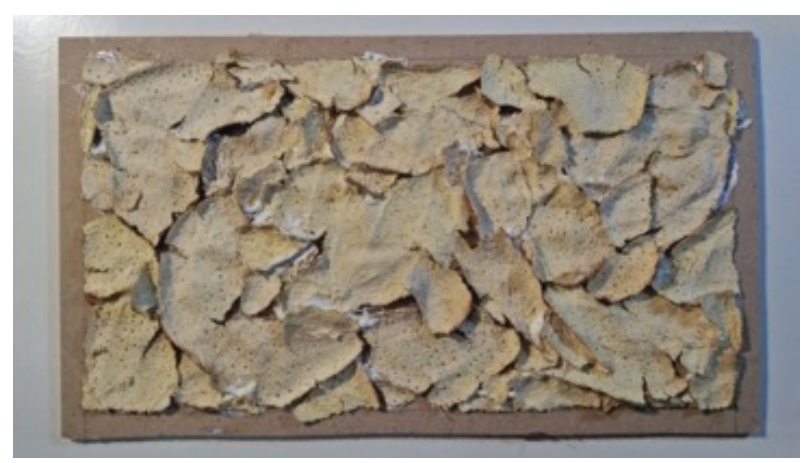

Gambar 19. Tafril kulit jeruk kering sebelum dilukis (Junaedi dan Tanos) 


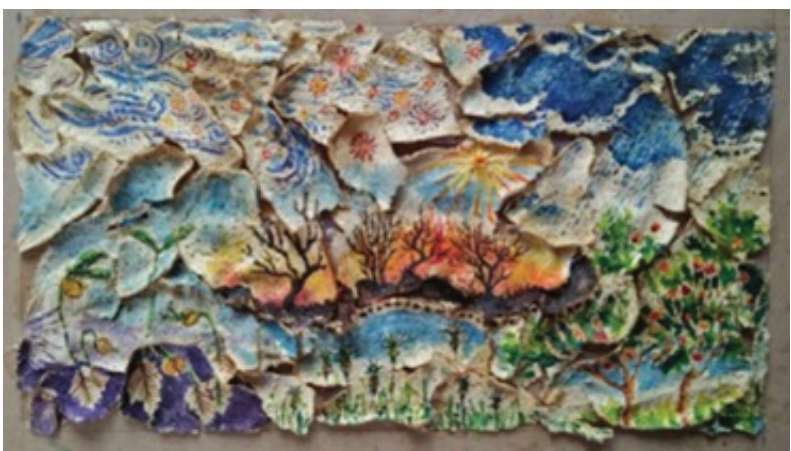

Gambar 20. Hasil lukisan cat air pada tafril kulit jeruk kering (Junaedi dan Tanos)

\section{Tafril Kulit Kacang Kering}

Lukisan selanjutnya dibuat dengan tafril kulit kacang kering. Pengeringan tidak dilakukan sendiri tetapi kulit kacang diambil dari kacang kemasan siap saji yang telah kering. Permukaan yang dipakai adalah sisi bagian luar, karena bagian dalam terdapat selaput tipis yang mudah mengelupas dan cenderung berminyak. Bahan ini direkatkan pada MDF menggunakan lem tembak.

Karakter kulit kacang adalah berteksture kasar, dengan demikian kurang cocok untuk bentuk lukisan yang penuh detail. Warna kulit kacang cukup terang sehingga dapat digunakan untuk sifat transparan cat air. Akan tetapi beberapa kulit kacang yang cacat berwarna coklat tua, pemilihan perlu dilakukan agar mendapatkan hasil yang sesuai. Warna kulit kacang yang tua tetap dapat digunakan jika ditempatkan pada bagian tertentu untuk direspon.

Berbeda dengan lukisan sebelumnya, cat air untuk karya ini ditambah dengan warna putih. Penambahan ini membuat sifat transparan cat air berkurang. Eksperimen ini dilakuakan untuk mendapatkan alternatif penutupan cat pada tafril. Hasilnya adalah, warna tafril dapat benar-benar tertutup, namun cara ini mengurangi karakter warna tafril karena tidak tereksplorasi.

Data lukisan kedua dalam penelitian ini adalah sebagai berikut, judul: "Tafril Kulit Kacang Kering untuk Lukisan Cat Air"; tahun: 2019; bahan: cat air, kulit kacang kering, mdf, lem tembak, fixatif; ukuran: 18 x $18 \mathrm{~cm}$.

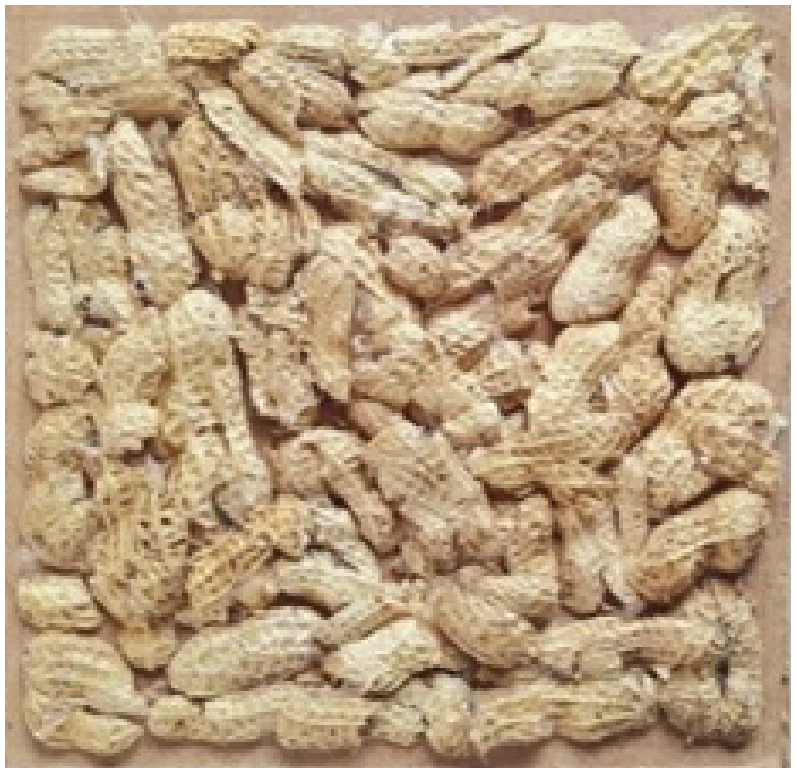

Gambar 21. Tafril kulit kacang kering sebelum dilukis (Junaedi dan Tanos)

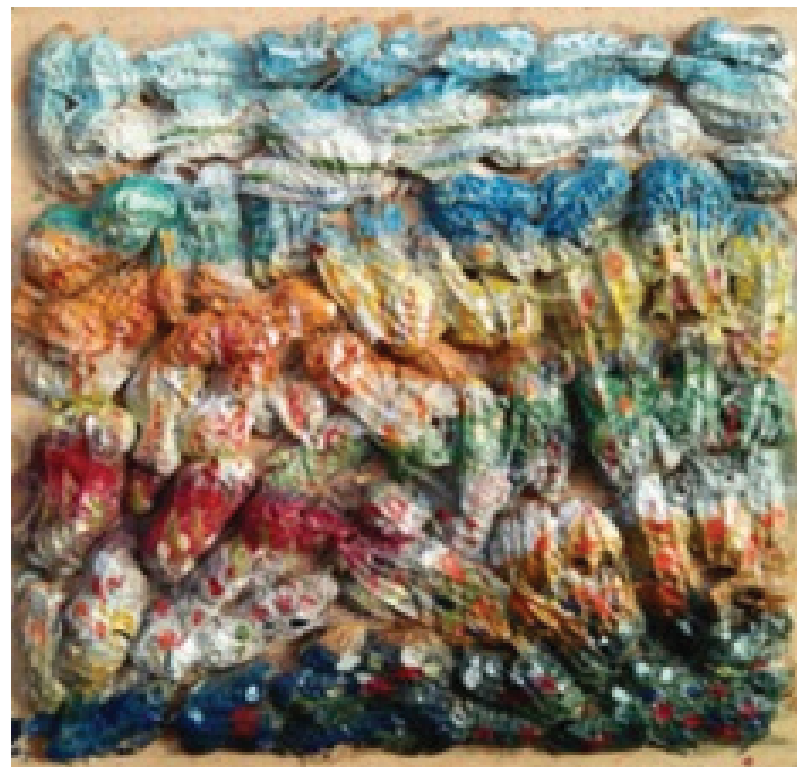

Gambar 22. Hasil lukisan cat air pada tafril kulit kacang kering (Junaedi dan Tanos)

\section{Tafril Daun Pisang Kering}

Lukisan terakhir untuk penelitian ini menggunakan tafril daun pisang kering. Bebeda dengan kulit jeruk maupun kulit kacang yang cenderung berongga, daun pisang relatif datar, sehingga penempelan ke MDF dapat menggunakan lem kayu yang lebih encer jika dibandingkan dengan lem tembak.

Warna daun pisang kering cenderung lebih tua, kecoklat-coklatan, jika dibandingkan kedua bahan sebelumnya. Penggunaan warna 
putih tidak terhindarkan untuk mencapai tonalitas terang yang maksimal. Tekstur daun pisang kering relatif lebih rata, detail lebih memungkinkan untuk tekstur jenis ini. Kelemahan tafril ini adalah permukaannya yang licin berminyak, sehingga daya serapnya terhadap cat air lemah.

Data lukisan kedua dalam penelitian ini adalah sebagai berikut, judul: "Tafril Daun Pisang Kering untuk Lukisan Cat Air”; tahun: 2019; bahan: cat air, kulit jeruk kering, mdf, lem tembak, fixatif; ukuran: 13 x $22 \mathrm{~cm}$.

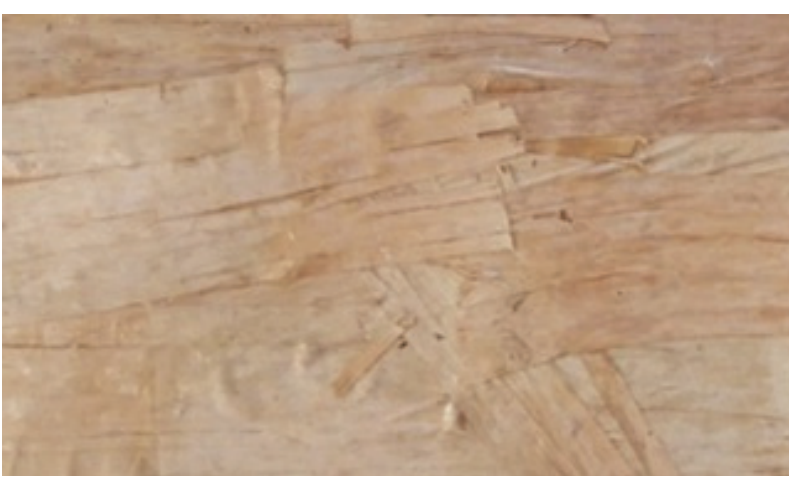

Gambar 23. Tafril daun pisang kering sebelum dilukis

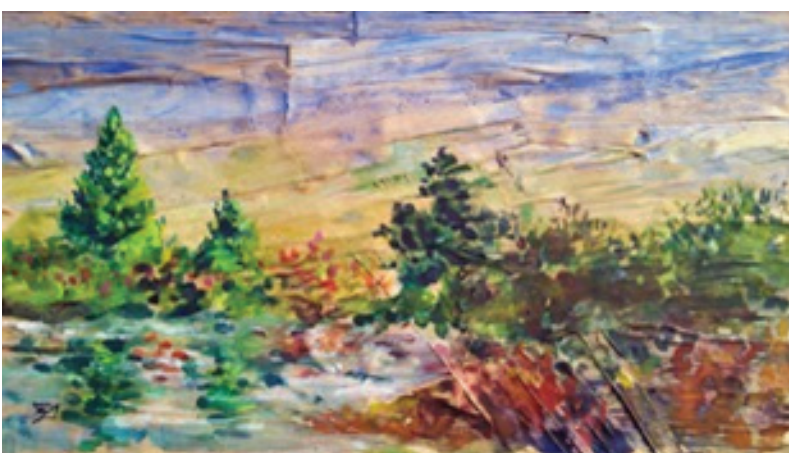

Gambar 24. Hasil lukisan cat air pada tafril daun pisang kering

\section{Kesimpulan}

Sebagai pengganti kertas, bahan-bahan dari tumbuhan kering dapat digunakan sebagai tafril lukisan cat air. Akan tetapi, beberapa hal perlu diperhatikan untuk memilih bahan alami tersebut. Hal tersebut meliputi daya serap, warna dasar, dan tekstur.

Tafril berbahan alami dari tumbuhan kering memiliki daya serap berbeda-beda, dari kuat hingga lemah. Pori-pori yang tampak pada permukaan bahan tersebut menjadi salah satu tanda bahwa bahan tersebut memiliki daya serap tinggi. Tafril dari tumbuhan kering yang memiliki daya serap tinggi adalah kulit jeruk kering maupun kulit kacang kering. Bahan yang daya serapnya rendah adalah daun pisang kering. Karena cat air bersifat dasar transparan, tafril perlu dipilih yang memiliki warna dasar terang, meskipun tidak benar-benar putih. Tafril dari bahan alami tumbuhan kering memiliki warna dasar beragam, dari yang berwarna krem muda hingga coklat tua. Bahkan ada kemungkinan memiliki warna belang. Tafril yang memiliki warna muda adalah kulit jeruk kering dan kulit kacang kering, sedangkan daun pisang kering cenderung coklat.

Tabel 1. Karakter Jenis Tafril Berbahan Tumbuhan Kering

\begin{tabular}{|l|l|l|l|}
\hline & Warna Dasar & Daya Serap & Tekstur \\
\hline $\begin{array}{l}\text { Kulit } \\
\text { jeruk } \\
\text { kering }\end{array}$ & Terang & Kuat & Medium \\
\hline $\begin{array}{l}\text { Kulit } \\
\text { kacang } \\
\text { kering }\end{array}$ & Terang & Agak Kuat & Kasar \\
\hline $\begin{array}{l}\text { Kulit } \\
\text { pisang } \\
\text { kering }\end{array}$ & Agak Tua & Lemah & Halus \\
\hline
\end{tabular}

Tekstur atau nilai raba yang tidak terlalu kasar cocok untuk lukisan cat air. Jika tekstur terlalu kasar tidak cocok untuk membuat bentukbentuk detail atau rincian. Sebaliknya, jika terlalu halus cenderung licin dan terasa kurang artistik. Tekstur yang tepat berasal dari bahan kulit jeruk kering. Tekstur kulit kacang kering terlalu kasar dan tekstur daun pisang kering terlalu halus.

Tabel. 1 menunjukkan karakter tafril bahan alami dari tumbuhan kering. Dari tabel tersebut tampak bahwa kulit jeruk kering merupakan tafril terbaik karena memiliki warna dasar yang terang, daya serap yang kuat, dan tekstur yang tidak terlalu kasar dan juga tidak terlalu halus, medium. Adapun tafril dari daun pisang kering merupakan bahan yang tidak bagus jika dibandingkan yang lain, karena warna dasarnya cenderung tua, daya serapnya lemah, dan teksturnya terlalu halus. Kelebihan daun pisang adalah ukurannya yang lebar sehingga lebih cepat menutup panel MDF dalam pembuatan tafril, akan tetapi hal ini tidak otomatis membuat karya lebih artistik. 


\section{Daftar Pustaka}

Appellof, Marian E. (1992). Everything You Ever Wanted to Know About Watercolor. New York: Watson-Guptill Publications.

Comella, M. Angels. (1996). Watercolor. London: A \& C Black.

Evitadyan, Ratna Adenia and I. Nyoman Lodra. (2015). "Eksperimen Media Melukis Dengan Kertas Foto 'Terbakar' Volume 3 Nomor 1 Tahun ,." Pendidikan Seni Rupa 3 (

Garcia, Joe. (2002). Mastering the Watercolor Wash. Cincinnati: North Light Books.

Greer, Hugh. (2010). “Snow Demo.” Watercolor Studio 6(2).

Hasyim, Asy'ari Moch. and Siti Mutmainah. (2013). "Eksperimen Pencampuran Pewarna Cat Air Dengan Zat Cair (Non Air)." Pendidikan Seni Rupa 01(01)

Junaedi, Deni and Adnan Aditya K. (2017). Komposisi Efek Spontan Cat Air Dengan Sulur Tradisional Yogyakarta Pada Penciptaan Lukisan. Yogyakarta.

Junaedi, Deni and Jacqueline Jesse Blues Tanos. (2018). Komposisi Warna Split Komplementer Untuk Penciptaan Lukisan Lanskap Cat Air. Yogyakarta.

Junaedi, Deni and Satrio Hari Wicaksono. (2018). Estetika Closure Dengan Efek Cat Air Pada Praktek Melukis Langsung Di Luar Studio. Jakarta.

McCracken, Laurin. (2011). "Techniques from a Studio Painter." Watercolor Studio 7(2).

Nur, Ahadien Raidy and Winarno. 2018. "Kajian Media Pada Karya Lukis Beng Herman Periode Tahun 2013-2015." Pendidikan Seni Rupa 06(01) 